\title{
DIGITALIZATION IN THE FIGHT AGAINST CORRUPTION IN UKRAINE
}

\author{
Silenko A. A.
}

\section{INTRODUCTION}

The relevance of the article is due to the fact that in 2019. in the ranking of Corruption Perception Index, Ukraine took 127th place among 180 countries. Among neighbors, the worst performance is only in Russia ${ }^{1}$.

According to the results of a sociological survey conducted in 2018. Ilk Kucheriv Foundation for Democratic Initiatives, together with the sociological service of the Razumkov Center on August 16-22 in all regions of Ukraine, except Crimea and the occupied territories of Donetsk and Lugansk regions, $26.1 \%$ of Ukrainians are ready to rally against corruption ${ }^{2}$.

This is three times IU nshe than 2012- 2013 g., While according to the study's Global Corruption Barometer (of Global Corruption Barometer) from by Transparency International, and Gallup International, Association viyasnilos that protest against corruption are ready $68 \%$ of Ukrainians ${ }^{3}$.

Do these research findings suggest that corruption has decreased? Unfortunately not. By orruptsiya Prodo lzhaet to be one of the most dangerous problems that hinder the development of Ukraine. Corruption discourages investors, hinders the full filling of the budget, destroys state institutions, the political system, and threatens national security.

According to Article 20 of the UN Convention against Corruption, the concept of non- legal enrichment "is understood as" a significant increase in the assets of a public official in excess of his legal income, which he can not reasonably substantiate. The world community recognizes the usefulness of recognizing illegal enrichment "as a criminal offense when it is committed intentionally", because the discrepancy between the declared income and the real costs of corrupt officials is much easier to justify than their specific corruption actions ${ }^{4}$.

${ }^{1}$ Рейтинг восприятия коррупции: Украина поднялась выше, но до сих пор отстает от соседей. Available from https://www.bbc.com/ukrainian/news-russian-47041703

${ }^{2}$ Если власть не прибегнет к насилию: эксперты рассказали, готовы ли украинцы выходить на акции протеста. Available from: https://styler.rbc.ua/rus/zhizn/esli-vlast-pribegnetnasiliyu-eksperty-rasskazali-1536955375.html.

${ }^{3}$ Каждый третий в Украине готов выйти на улицу из-за коррупции. Available from: http://www.pravda.com.ua/rus/news/2013/07/9/6993866/.

${ }^{4}$ Борьба с коррупцией - зарубежный опыт: от Швеции до Сингапура. Available from: http://argumentua.com/stati/borba-s-korruptsiei-zarubezhnyi-opyt-ot-shvetsii-do-singapura. 
In fairness, it should be noted that corruption is a problem not only in Ukraine. It is in almost all countries to one degree or another. And the fight against corruption is not always successful. So, despite the fact that such authoritative international organizations as the World Bank, the European Commission, Transparency International take an active part in anti-corruption reforms in the countries of Central and Eastern Europe, corruption has not been overcome. Rasmo Karklinks writes about this in his work "The system forces me to do this", that despite the increase in anti-corruption measures in post-communist countries, their implementation did not lead to a real increase in accountability, due to a lack of political will, as a result of which the trend towards the formation of informal networks intensified, the development of patrimonialism, clientism, nepotism and the like practices" ${ }^{5}$.

And it appeared not today, but from the moment the state appeared as a socio-political institution. The problem of corruption was very worrying for Napolen, who considered it extremely dangerous for the army and the state. In order to combat the embezzlement and theft of army resources, a special system was developed that regulates public procurement ${ }^{6}$.

Corruption has become the subject of scientific writings of the famous philosophers Platon, Aristotle, T. Hobbes, N. Machiavelli, S. Montesquieu and others. The great sociologists E. Durkheim, G. Simmel, M. Weber, T. Parsons presented their views on this problem. R. Merton, P. Berger and others. The problems of electronic government were dealt with by Ukrainian researchers E. Emelianenko, I. Kusplyak, N. Kruk and others.

Note that the purpose of this article is to prove that digitalization can influence corruption and reduce its level. However, we do not claim that digitalization is the main way to fight corruption. Although such stereotypes exist today in domestic and foreign literature. Of course, other factors, for example, socio-cultural and psychological, play an important role in creating an anti-corruption environment.

You can share a few basic factors that influence the effectiveness of launching e electrons government in Ukraine.

\section{The willingness of the population to the EC to use the e-government}

One of the most important indicators of lifestyle changes in the second half of our century is the development and use of new information and communication technologies in all areas of social life and activity, the level of production and consumption by society of information products and services.

${ }^{5}$ Karklins, R. (2005). The System Made Me Do It: Corruption in Post-communist Societies. Armonk, New York: M.E. Sharpe, p. 16-17.

${ }^{6}$ Поляков М.М. Европейский опыт борьбы с коррупцией органами исполнительной власти и прокуратуры. Available from https://cyberleninka.ru/article/n/evropeyskiy-opyt-borbys-korruptsiey-organami-ispolnitelnoy-vlasti-i-prokuratury. 
Apparent change of attitude to information resources and the expansion of production and application of information capabilities to enhance human potential and its development in many district and boards. Such opportunities in modern society are provided by the e-government system. Is the Ukrainian population ready to take advantage of electronic services that are designed to greatly facilitate the lives of citizens?

An analysis of the situation in Ukraine shows that there are factors that impede the approximation of e-government to the needs of people. First of all, this is a low level of Internetization of the population, especially in rural areas. According to a study conducted by Factum Group, a research company commissioned by the Internet Association of Ukraine, the number of regular Internet users by the end of Q3 2019 increased by 7\% to 22.96 million, the share of Internet users is $71 \%$ (22.96 million), 65\% have internet at home. The most active Internet users, of course, are young people. According to the study, "almost the entire population of Ukraine under the age of 35 are Internet users" 7 .

Thus, people of respectable age who do not have the skills to use information and communication technologies cannot use the services of egovernment. Electronic receptions, which were conceived to facilitate access to the e-government system, were never created. It became clear that in conditions of total underfunding it is impossible to organize the work of specialists in advising citizens and servicing equipment. Yes, there are Internet clubs, Internet cafes, but as practice has shown, their audience is exclusively young people spending their leisure time there.

The fact that in recent years the number of Internet users in Ukraine has increased by $7 \%$ is positive. However, this does not mean an increase in the number of users of the e-government system. We have to admit that the social demand for electronic services is still low in Ukrainian society, and this is one of the serious obstacles to the development of electronic government. The reasons are different. Some citizens doubt the availability and quality of electronic services. Many citizens worry about the confidentiality and secrecy of their personal data. And these fears are not unfounded. As you know, in Ukraine you can purchase any electronic database with personal data, including those for which law enforcement agencies are responsible. Credit scammers take money from credit cards and steal confidential information. Naturally, all this is done by people, not the Internet, but as a result of this, citizens are distrustful of new technologies.

We can not ignore that, thanks to information and communication technologies, we cannot ignore that, thanks to IT, the government is gaining new opportunities for control over society. And the state does not necessarily become

${ }^{7}$ Количество пользователей интернетом в Украине выросло на 7\% - исследование. Available from https://www.epravda.com.ua/rus/news/2019/10/11/652498/. 
more open. It cannot be argued that the unified government bases created in many countries of the world with a huge amount of confidential and personal information about each individual person will be used only to improve the quality of public services. So, as it would have to be in a democratic environment with the control of society over the activities of the authorities. For example, in the United States, Internet policy has been heavily criticized. Namely, various organizations for the protection of civil rights and freedoms of consumers express concern about the increase in the number of cases of unauthorized use of personal data. The wide, almost unlimited possibilities of modern computer technologies for the exchange, integration and classification of information make it possible, without much effort, to create an "information portrait" of the individual, allowing public and private institutions to use the information in their own interests. This circumstance, known to man, has a negative effect on his self-consciousness, causing the feeling of being under the close attention of these structures. According to Western scholars S. Cunningham and A. Porter, "databases compiled on people can lead to a person's loss of individual, private life and personal freedom, and provide an opportunity for discrimination on an unprecedented scale" ${ }^{\text {. }}$

It should also be borne in mind that not all citizens agree to learn how to use information technology. After all, this requires certain properties from a potential user, first of all, readiness to improve education. Only in this way is it possible to acquire the necessary skills for communicating with e-government.

The paradox is that with a large number of higher education institutions, the level of computer literacy among the Ukrainian population is low.

A major role in the process of preparing citizens for life in the information society is played by the state. C 2001 in the European Union, the eCitizen standard of the European Computer Driving License (ECDL) is being introduced as the official computer literacy standard. Based on this standard, the "Electronic Citizen" program is being implemented - the world's leading project for training beginners in personal computer skills. It would be advisable if Ukraine became an active participant in this program.

Recently it became known about the new program of the Ministry of Digital Transformation of Ukraine, within the framework of which it is planned to train 6 million. Ukrainians in three years of digital literacy. The program is implemented in the format of the series, the creation of which will be attended by famous Ukrainians. As Minister Mikhail Fedorov stated on his page in the FB, "There are projects that are changing the country. Today we are launching an online educational platform for training digital skills of Ukrainians. Everyone should have the right to free education in this area.

${ }^{8}$ Каннингэм, С. (2000). Сетевые средства связи: двенадцать способов изменить нашу жизнь. Впереди XX1 век. Антология современной классической прогностики. М.: Academia. C. 96. 
Subsequently, this will become our national competitive advantage. It will be possible to study in any computerized library according to our program" ${ }^{9}$.

It follows that the creation of the program was preceded by a study that showed that " $53.5 \%$ of Ukrainians are below the average level in digital literacy. $15.1 \%$ of Ukrainians do not possess digital skills, and $37.9 \%$ of citizens have a low level of digital skills. The most vulnerable segment on the Internet is young people under 16 years old and people over 60 years old.”

Begin to educate an "electronic citizen" should be from school. Computer science should not be taught at school formally, as is happening now, when students are sometimes more familiar with information technology than a teacher. And at a high level - a professional teacher, a modern computer, the latest techniques and the required number of hours. To this end, changes to the school curriculum in computer science are needed. Therefore, it is logical that students are one of the target audiences of this program. The motivation for learning for schoolchildren and students is employment and the prospect of realization in the profession.

Also, the initiators of the implementation of this program consider it necessary to educate parents of children from three years of age and older who use electronic devices. It is estimated that parents will need special knowledge in order to protect their children from the negative impact of the Internet.

The next group is entrepreneurs who will be taught online security, digital marketing, etc. With a middle age, men in this group are 45 years old, women are 43 years old.

This is followed by an age group of 30 to 60 years. These are teachers, doctors, public servants, specialists from various directions of the private sector. They all need digital skills to enhance their competitiveness.

A particular problem is the teaching of computer literacy for older and older people. For this, a special state program is needed, thanks to which people of this age category will gain computer skills and the ability to work with information from the public services portal. This will help them maintain communication with loved ones, find the right information, and use administrative and social online services.

Another reason for computer illiteracy is the low level of material wellbeing of Ukrainian citizens. Ukrainian salaries and pensions do not match the prices of modern information gadgets. So, according to Valeria Ionan, Deputy Minister of Digital Transformation on European Integration, based on the results of a sociological study, in Ukraine $51 \%$ of families do not have a single computer, and $49.4 \%$ do not have a single laptop ${ }^{10}$.

${ }^{9}$ В Украине запускают сериал о цифровой грамотности. Available from: https://lb.ua/news/2020/01/21/447692_ukraine_zapuskayut_serial_tsifrovoy.html.

10 В Украине 51\% семей не имеют ни одного компьютера. Available from: https://news.finance.ua/ru/news/-/462589/v-ukraine-51-semej-ne-imeyut-ni-odnogo-kompyuteraissledovaniya. 
Interesting results were obtained in the course of study I influence the development of electronic public services and the level of corruption in the EU and in countries outside the EU. D. Lupu and K.G. Lazar suggested that citizens with remote access can use information and communication technologies to monitor the activities of state and municipal authorities, which will result in a reduction in corruption. They proved that a $1 \%$ increase in the e-government index could lead to a $6.7 \%$ reduction in corruption for EU countries and $6.3 \%$ for non-EU countries ${ }^{11}$.

\section{Willingness of officials to implement the e-government system}

Became popular, in the context of the election of President of Ukraine Vladimir Zelensky, the series "Servant of the People" got its name for a reason. The same goes for the new political party, which received in the 2019 parliamentary elections, stunning support from Ukrainian citizens. The screenwriters farsightedly focused on the social request of citizens for a democratic political system in which the state is a service organization whose employees provide public services to people. However, few people recall that for the first time the term "servant of the people" was voiced by Stalin on December 11, 1937 during a speech in one of the Moscow constituencies named in his honor.

New opportunities in the fight against corruption have appeared in the information society. International practice has shown that information technology allows, firstly, to reduce the role of the human factor in the process of managerial decision-making, and secondly, to more effectively involve citizens who previously preferred to remain critics of corruption rather than fighters against it in anti-corruption processes.

The term "digitalization" with a light hand of the new Ukrainian government became the word of the year according to the dictionary of the modern Ukrainian language and slang "Mislovo". According to the authors of the Dictionary, digitalization is "changes in all spheres of public life associated with the use of digital technologies". They call the phrase "digital transformation" the Ukrainian counterpart" ${ }^{12}$.

Speaking about the introduction of digitalization in all spheres of activity of Ukrainian society, the new government implies primarily electronic document management, digital signatures, open and accessible databases, and much more. The main goal is to liberate Ukrainians from paper bureaucracy,

${ }^{11}$ Lupu D., Lazar C.G. Influence of e-government on the level of corruption in some EU and non-EU states. Available from https://www.sciencedirect.com/science/article/pii/ S2212567115000854.

12 Неожиданно: в Украине назвали слово года, и это не «Зе» и не «монобольшниство». Available from https://fakty.ua/329170-ne-ze-i-ne-turborezhim-v-ukrainenazvali-slovo-goda. 
endless queues in state bodies and it has become a tradition for them to confirm the saying "you will not smear - you will not go".

Thus, the technical means at the disposal of the subjects play an important role in the implementation of information relations in politics, which makes us talk about the technical level of information and communication processes. It is the quality of technology that now provides the interaction of power and society.

It should be noted that attempts to introduce technologies of a "transparent office" in Ukraine have already been made. On March 12010 the order of the Cabinet of Ministers of Ukraine No. 360-r was issued on the implementation of a pilot project for the introduction of e-government technologies. At this disposal, the Ukrainian government agreed with the proposal of the State Informatization Committee on implementation in 2010 a pilot project on the introduction of e-government technologies in government bodies and local self-government bodies with the aim of creating the legal, scientific, technical, financial and economic conditions for the development of the information society.

The main objective of the pilot project was to identify a mechanism for solving problems associated with the functioning of electronic document management; ensuring the permanent storage of electronic documents and other electronic information resources, as well as information protection; development of formats of typical electronic documents of state authorities and local authorities; preparation of temporary regulations for electronic document management in executive bodies.

In 2013 the Government of Ukraine announced the opening of socalled "transparent offices" in all regions of Ukraine, which were supposed to provide citizens with administrative and social services. In 2014 the State Agency for E-Government Issues was created. Ukrainians were promised a new quality of work with citizens on the basis of the Unified Information and Analytical System of Social Protection of the Population. Also, as now, it was assumed the disappearance of paperwork, increasing the efficiency of use of funds. And, of course, minimizing the risk of abuse by officials ${ }^{13}$.

In 2016 the development of e-government has once again become one of the objectives of the Government's program of activities. However, the lack of a state strategy, the imperfection of the legislative score, and the lack of political will led to the result that we, alas, know. People still go from office to office for the necessary information, patiently stand in long hours, and.... continue to pay bribes.

In the UN ranking on the development of e-government in the world in 2018. Ukraine took 82 place. Compared with 2014 it is 5 points higher.

${ }^{13}$ Арбузов анонсировал создание «прозрачных офисов» во всех областях Украины. Available from http://podrobnosti.ua/power/2013/07/30/920480.html. 
However, there is no need to speak about the significant progress that every Ukrainian has felt on himself.

In this context, Dmitry Dubilet urgently called for combating corruption with the help of technology. By the way, Dmitry Dubilet is one of the few members of the government whose work results can be seen firsthand. It was he, together with a group of activists, who created the iGov portal, on which 321 admin services are already available. Thanks to the portal, the citizen reduced the number of his visits to officials. Although at least once it is necessary to appear to officials, however, no doubt, progress has been made. At the same time, this fact weakens the effectiveness of this system. To receive a bribe, an official needs only one visit from a client. Moreover, where are the guarantees that even when a personal meeting between the official and the client is not needed, the official will not hide it and call the client?

Another attempt to introduce electronic services in Ukraine was made recently in 2018.

The purpose of the Trembita information system is to provide government agencies with the opportunity to exchange electronic registries in real time. Working to improve this system, Ukrainian experts rely on the experience of Estonia, which is very progressive in the development of the e-government system. Estonian IT-system « the X-Road General Description " allows you to receive e-service from anywhere in the world within minutes. Thus, saving money and time for citizens and officials, eliminating the causes of corruption. According to reports, in 2018 the system processed almost 1 billion requests, and in February 2019 - 104 million requests. In 2018, X-Road saved 1,407 working years or 12.3 million working hours for Estonian citizens. In total, 2,595 public services are available online in Estonia. Every year an Estonian citizen uses 100-120 electronic public services and every year, electronic public services save an Estonian citizen 10 days of life ${ }^{14}$.

In our opinion, the experience of Singapore is also useful for Ukraine, which during the creation of e-government was guided by the principle "Any public service, if possible, should be provided in electronic form". What Singapore has managed to achieve today is absolutely necessary in Ukraine: transparency of the process of providing public services, increasing the efficiency of public administration, reducing corruption, improving communication between the state and society. An interesting point for understanding the Singaporean e-government system is the fact that if a citizen comes to a government agency for a service that can be obtained electronically, he can be fined.

${ }^{14}$ Как будет выглядеть "цифровая" Украина: репортаж из Эстонии. Available from https://www.epravda.com.ua/rus/publications/2019/03/18/646173/. 
Adopted Law of Ukraine "On Electronic Digital Signature" dated May 22, 2003. (Law on EDS), which is the basis of electronic document management, the Law of Ukraine "On Payment Systems and Money Transfer in Ukraine" dated April 5, 2001. (Law on Payment Systems) and the Law of Ukraine "On Electronic Documents and Electronic Document Management" dated May 22, 2003. (The Law on Electronic Documents) gave hope that the formal exchange of information between users and government bodies would be the beginning of effective promotion of Ukraine to electronic government, that the main form of use by state bodies of modern communication technologies would be the integration of information systems of individual departments into a single network. However, so far this has not happened. The main form of use by state bodies of modern communication technologies will be the integration of information systems of individual departments into a single network.

In Ukraine, the conditions for the full launch of the electronic government are still being created. Sometimes the success of this process depends on the goodwill of the ministries. And the situation is like that, or all, or nobody. So that, if, for example, the Ministry of Education or Health does not connect to the system of electronic services, the efforts of others can become meaningless.

One of the reasons for this situation is the official's lack of interest in introducing informational innovations into the management process. After all, innovation contributes to a reduction in the budget, a reduction in personnel and, accordingly, a reduction in licensing functions.

On this occasion, the Ukrainian researcher N. Kruk rightly writes that "the reasons for the resistance of officials to the introduction of information transparency are: the discrepancy between their interests and the interests of society; lack of motivation due to a lack of understanding of the goals of modernizing state power; loss of power and influence, persisting due to the existing monopoly on information; decrease in official status; insufficient level of technical competence, etc.” 15

If 5-10 years ago in Ukraine there was an urgent problem of training public servants open for the implementation of information and communication technologies, since there was great resistance to the conservative part of the state apparatus. Today we are faced with a new problem, new officials who have replaced the previous ones have a low level of competence and a lack of experience in solving state problems.

An increasing number of websites of various government bodies, party structures, and numerous international non-governmental organizations appear

15 Крук Н. В. (2014). Інформаційна відкритість як принцип діяльності органів державної влади, дис. ... канд. політ. наук. 23.00.02 - політичні інститути та процеси. Одеса, 178 с. 
on the Web, containing a variety of information that significantly increases the political awareness of the masses. A variety of government publications that previously were available to only a few are becoming publicly available. The Internet is stimulating the emergence of new, effective mechanisms for political mobilization of citizens. Without exaggeration, it can be considered a means of rather prompt organization and coordination of actions of political like-minded people who are supporters of non-traditional social movements.

As a result of monitoring of 65 official websites of the central and 25 websites of local authorities of Ukraine, conducted by the State Committee for Television and Radio Broadcasting in the first half of 2019 official websites of the Ministry of Agrarian Policy, the Ministry of Infrastructure, the Ministry of Information Policy, the State Service for Medicines and Drug Control, the State Labor Service, the State Emergency Service, and the Administration of the State Border Service of Ukraine are recognized the best.

The official websites of the Khmelnitsky, Volyn, Poltava, Zaporizhzhya, Dnipropetrovsk, Kharkiv, Zhytomyr, Ivano-Frankivsk, Transcarpathian, Rivne, Kherson and Chernihiv regional state administrations are identified as leaders in the rating among local executive authorities облгосадминистраций ${ }^{16}$.

Most sites use information level modes (providing direct information about state (administrative) services and one-way interaction (the user can receive an electronic form of a document). At the same time, two-way interaction modes are not yet widespread (the electronic form of a document cannot be processed, including identification) and transactions.

All central executive bodies provide information services at the level of informing about the service: name of service; administrative authority that provides the service; regulatory documents that govern the provision of services; consulting materials.

It is important to remember that not only anti-corruption, but also corrupt officials who successfully use electronic services for criminal purposes have learned new information technologies.

The well-known human rights organization Transparency International recommended to Ukraine in 2019 the following anti-corruption measures: restart NAPK; implement proper automatic verification of declarations and monitoring the standard of living of declarants; ensure the effective operation of the beneficiary registry; continue public procurement reform; corporatize and privatize state-owned enterprises; strengthen control over the financing of political parties (Corruption Perception Rating...). Two of these recommendations, in particular, automatic verification of declarations and public

\footnotetext{
${ }^{16}$ Назвали лучшие сайты органов исполнительной власти. Available from: https://www.ukrinform.ru/rubric-society/2733826-nazvali-lucsie-sajty-organov-ispolnitelnojvlasti.html.
} 
procurement reform, are directly dependent on information technology. It would seem that openness and automation will help narrow the field for corruption. However, in practice, it turned out that new technologies are not a panacea in the fight against corruption. A Declaration checked selectively, and public procurement organized by the scheme to circumvent anti-corruption Prozorro benefits system, which aims to transparency in government procurement and thus decrease the risk of corruption. To corruption officials easily found ways to conduct their schemes through this system. An analysis of the tenders passed through Prozorro shows that the most profitable of them were held with one participant. And this allows us to conclude a preliminary conspiracy ${ }^{17}$.

\section{CONCLUSIONS}

The foregoing allows us to draw some conclusions. The rapid development of information tools and technologies in the twentieth century has made information a direct engine of progress. In fact, we are witnessing the formation of a new, more effective form of self-organizing civil society. Civil society and the IT sector in Western countries became the first active users of information and communication technologies. With oday they derive great benefits from the use of digital opportunities to overcome corruption. Will Ukraine go this way? Obviously, yes, since today there is no other choice, except for how to actively use new information technologies and respond quickly to the challenges of the information society.

E-government is the use of information and communication technologies to transform government in order to make it more accessible to citizens, more efficient and more accountable. Thus, e-government does not mean a simple increase in the number of computers among officials. We are talking about global changes affecting the relationship between public servants and citizens.

E-government in Ukraine is possible under certain conditions, in particular, the readiness of state authorities and the willingness of citizens to become users of e-government.

State readiness implies orientation towards citizens, bridging the digital divide, professionalism and computer literacy of officials, effective organization, and, of course, technical infrastructure. As many public services as possible should be provided in electronic form, which is why it is imperative to combine the websites of ministries and departments into a single information space.

Citizens' readiness includes computer literacy and a psychological attitude, without which they cannot take advantage of the benefits of the information society.

17 Prozorro: преодоление коррупции или выкручивание рук администраторам? Available from https://finstat.info/2018/04/prozorro-preodolenie-korruptsii-ili-vyikruchivanieruk-administratoram.html. 
The availability of information on the activities of authorities, political processes and events, contributes to the openness of political institutions, the involvement of interested sectors of society in the public administration process, which allows us to hope for the expansion of the conventional political participation of civil society, building a mobile dialogue in the context of mass consultations and coordination of various positions of the participants in the interaction.

\section{SUMMARY}

The article discusses the role of digitalization in the fight against corruption in Ukraine. It is noted that digitalization is an important, but not the only factor that positively affects the reduction of corruption. It is shown that information technology is not a panacea for corruption, so not only anticorruption, but corrupt officials who successfully overcome electronic traps get new opportunities. In s fissile few basic factors influencing the efficiency of the launch of e-government in Ukraine. This willingness of the public and officials to the introduction of e electrons government. The experience of Estonia and Singapore in terms of its usefulness for Ukraine is considered.

\section{REFERENCES}

1. Арбузов анонсировал создание «прозрачных офисов» во всех областях Украины. Available from http://podrobnosti.ua/power/2013/ 07/30/920480.html.

2. Борьба с коррупцией - зарубежный опыт: от Швеции до Сингапура. Available from http://argumentua.com/stati/borba-s-korruptsieizarubezhnyi-opyt-ot-shvetsii-do-singapura.

3. В Украине запускают сериал о цифровой грамотности. Available from: https://lb.ua/news/2020/01/21/447692_ukraine_zapuskayut_serial_ tsifrovoy.html.

4. В Украине 51\% семей не имеют ни одного компьютера. Режим доступа: https://news.finance.ua/ru/news/-/462589/v-ukraine-51-semej-neimeyut-ni-odnogo-kompyutera-issledovaniya.

5. Если власть не прибегнет к насилию: эксперты рассказали, готовы ли украинцы выходить на акции протеста. Available from: https://styler.rbc.ua/rus/zhizn/esli-vlast-pribegnet-nasiliyu-eksperty-rasskazali1536955375.html.

6. Каждый третий в Украине готов выйти на улицу из-за коррупции. Available from: http://www.pravda.com.ua/rus/news/2013/07/ 9/6993866/.

7. Как будет выглядеть «цифровая» Украина: репортаж из Эстонии Режим доступа: https://www.epravda.com.ua/rus/publications/2019/03/18/ $646173 /$. 
8. Каннингэм, С. (2000). Сетевые средства связи: двенадцать способов изменить нашу жизнь. Впереди XX1 век. Антология современной классической прогностики. М.: Academia, 480 c.

9. Количество пользователей Интернетом в Украине выросло на 7\% - исследование. Available from: https://www.epravda.com.ua/rus/ news/2019/10/11/652498/.

10. Крук Н. В. (2014). Інформаційна відкритість як принцип діяльності органів державної влади, дис. ... канд. політ. наук. 23.00.02 політичні інститути та процеси. Одеса, 178 с.

11. Назвали лучшие сайты органов исполнительной власти. Available from: https://www.ukrinform.ru/rubric-society/2733826-nazvalilucsie-sajty-organov-ispolnitelnoj-vlasti.html.

12. Неожиданно: в Украине назвали слово года, и это не «Зе»и и не «монобольшниство». Available from: https://fakty.ua/329170-ne-ze-i-neturborezhim-v-ukraine-nazvali-slovo-goda.

13. Поляков М.M. Европейский опыт борьбы с коррупцией органами исполнительной власти и прокуратуры. Available from: https://cyberleninka.ru/article/n/evropeyskiy-opyt-borby-s-korruptsieyorganami-ispolnitelnoy-vlasti-i-prokuratury.

14. Рейтинг восприятия коррупции: Украина поднялась выше, но до сих пор отстает от соседей. Available from: https://www.bbc.com/ ukrainian/news-russian-47041703.

15. Karklins, R. (2005). The System Made Me Do It: Corruption in Post-communist Societies. Armonk, New York: M.E. Sharpe, 219 p.

16. Lupu D., Lazar C.G. Influence of e-government on the level of corruption in some EU and non-EU states. Available from: https://www.sciencedirect.com/science/article/pii/S2212567115000854.

17. Prozorro: преодоление коррупции или выкручивание рук администраторам? Available from: https://finstat.info/2018/04/prozorropreodolenie-korruptsii-ili-vyikruchivanie-ruk-administratoram.html.

\section{Information about the author:} Silenko A. A., Doctor of Political Sciences, Professor, Vice-Rector, Odessa National Academy communication of A. S. Popov 1, Cuznechna str., Odessa, 65000, Ukraine 